Liudmila A. Alyabieva

Ph D., Associate Professor at Faculty of Communications, Media, and Design / HSE Art and Design School, Academic Director of the Doctoral School in Arts and Design at the Higher School of Economics Research University (Moscow)

e-mail: lalyabieva@hse.ru

Moscow, Russia

ORCID 0000-0001-7795-2059

ResearcherID Z-1306-2019

Irina M. Sakhno

Doctor of Philology, Professor,

Department of theory and history of culture, RUDN University, Moscow

Academic Supervisor, Masters Program "Practices of Contemporary Art Faculty of Communications, Media, and Design / HSE Art and Design School e-mail: sakhno_im@pfur.ru

Moscow, Russia

ORCID 0000-0002-5510-6684

ResearcherID B-2047-2016

Scopus Author ID 57196349789

Tatiana E. Fadeeva

PhD in Art history, Associate Professor

Faculty of Communications, Media, and Design / HSE Art and Design School

e-mail: tfadeeva@hse.ru

Moscow, Russia

ORCID 0000-0002-6754-4235

ResearcherID Z-2521-2019

\title{
INNOVATIVE FORMS OF EDUCATION IN ART AND DESIGN: OVERVIEW AND PROSPECTS
}

Summary: The latest educational technologies and courses in art and design are the focus of this paper. Various practice-based graduate courses such as the practicebased Ph.D., the Art Ph.D., practice-based research, and practice-led research, and others, are of particular interest. The authors argue that traditional education is no longer capable of meeting today's smart society's needs with its focus on information, technology, and creativity. By establishing convergent teaching principles, these new graduate courses provide career-oriented education that fuses theory and practice. These innovative courses aim to reinforce practical/applied and research skills and bring together theoretical findings and practical representation forms. With today's growing interest in projectbased and practice-based research, the authors examine the evolution of educational and academic standards and analyze the background of project-based activity in art and design education. Based on their in-depth study of international experience and postgraduate European art and design programs, they draw a range of conclusions and take a detailed look at practice-based research Ph.D.

As Ph.D. programs become more diverse and the choice is continually growing, the authors feel that the traditional teaching and research role of a Ph.D. student is becoming outmoded. Becoming a key resource for creating innovative Ph.D. programs, today's practice-based Bachelor's and Master's degrees in art and design focus on applied research, the effectiveness of which is beyond question. Practice-based Ph. Ds, which are increasingly becoming the subject of academic debate, clearly show the shift taking place in views on graduate study standards. In today's educational and academic learning models, the dichotomy between theory and practice is erased with practical research bringing together methodologies based on academic and practical results. The development of integrative methodology is greatly advanced through practical 
research cases, the effectiveness of which largely depends on the educational establishment's management's dedication to updating traditional learning formats. The paper offers a brief review of the leading practice-based Ph.D. discussion platforms while also introducing a wide variety of foreign-language sources, in which this new phenomenon and various practical research models are analyzed, into the academic field.

Keywords: Graduate school, Ph.D. by Practice, art, Art Ph.D., design, Practice-based research, Practice-led research.

\section{Formulation of the Problem}

The lack of academic community consolidation on the problem of practice-based master's and postgraduate programs exists, among other things, due to the outdated education model, which has not been revised for a long time. Until recently, practice was not considered a priority format of training for academic scientific standards, and secondary vocational education institutions formed practical skills. Theoretical researchers' interest in practical projects mainly arose when they studied a specific corpus of works and posed logical questions: "How has this been done? For what purpose? In what cultural and historical realities did the artifact appear?" The answers required an appeal to the format of the case studies. Today, modern educational technologies make it possible to organize the educational process in a higher school in a new way and update students' professional orientation. In our opinion, new Ph.D. formats can become that innovative educational platform that will make it possible to implement the mandatory components of vocational education in higher education and develop creative and integrative competencies necessary in the changing world. We would like to reflect on the debatable issues and offer our position on practice-based postgraduate studies. It is quite apparent that the previous educational model does not meet the requirements of training a high-class specialist with multidisciplinary competencies who can theoretically comprehend the research problem and offer innovative tools for the implementation of design solutions.

Why? Firstly, today the idea of who a modern artist is and what the essence of their work is has changed. For a long time, theorists tended to perceive an artist as a demiurge who did not understand the work's coded meanings and, therefore, needed an interpreter art critic who put the artist's creative heritage in the appropriate context. However, today, contemporary artists work at a very high intellectual and conceptual level, reflected both in their works and in the reflections that accompany them (taking into account the existing frames, contexts, and paradigms). Today, artists and designers enter academies of arts to get new tools for working with the material. For many artists and designers, the opportunity to comprehend their practice at a systemic level, provided by the academy, serves as a trigger for reflection and forms a trajectory for further development in the professional subject field.

Secondly, theorists are increasingly turning to work with the material, to texture, and to thinking through making [16, p.11], moving from abstract constructions to field research. Many people start with "mental experiments" and move on to their direct implementation. For example, a researcher in game studies may be interested in what happens if some kind of "anti-game" is created, a game in which something that makes a game a game is absent. A legitimate question arises whether this will be a game, how it might look, and how it will affect our understanding of the game. Subsequently, a researcher can create a model of such a game and try to implement their hypotheses in practice, independently or within a research group's framework. In our work, we will give examples of several such cases. It should be added that the "theoreticians" and "practitioners", integrating into their activities and into practice and theory, face difficult methodological challenges and must, in fact, perform "double work". So, according to the results of training in a practice-based postgraduate study, an applicant for a scientific degree is obliged not only to write a scientific work but also to implement a project; thus, making not only a theoretical but also a practical contribution to the relevant subject area.

In the context of this research, the research residency format is also of great interest, which emerges as a "symmetrical response" to the already existing format of an art residence (Artist-in-Residence model, AiR). An art residence is a place where the creative forces of artists and designers accumulate. There are many different options for such residences. Artistic strategies vary from residence to residence some focus on teamwork on a specific project in production workshops, others involve creating independent projects from scratch, and so on. Art residences are usually implemented based on various institutions (from museums and galleries to 
directorates for the management of city parks and squares), including scientific ones. For instance, in the $\mathrm{UK}$, there is a long tradition of integrating practicing artists into the art academy (Artist-in-residence programs). In their article Embedded Aesthetics: Artistin-Residencies as Sites of Discursive Struggle and Social Innovation, Michael Lithgow and Karen Wall rightly note: " Artist residencies create affordances for experiment, learning and creation on the part of individual artists, social exchange and engagement, and/or cooperation among and between professions and disciplines" [21].

In addition to the Artist-in-Residence format, there is also an active development of the Researcherin-Residence format since most scientists would like their research to have a greater impact on practice. Back in 1983, D. Schön noted that there was a problem of insufficient integration of theory and practice: "In recent years, it has become more and more obvious that scientists who must pass on useful knowledge to the professional community are less and less able to say something that is of value to practitioners". [28, p.10]. In her speech at the DESIRE2011 conference in Eindhoven, Linda Candy noted an important factor: "There is an important difference between theory that is applied to practice $\langle\ldots\rangle$ and theory that is derived from practice. In creative practice, practitioners do more than draw upon an existing repository of theoretical knowledge: they make new works through experimentation and evaluation and, in doing so, come to new understandings about what works well." [10]. Referring to Graeme Sullivan's statements, she discusses the prospects for such an approach: "As Graeme Sullivan notes, we can realize the shortcomings of existing approaches to the search for solutions owing to practice accompanied by reflection as a method of solving problems, which includes a cyclical learning process in the course of performing specific actions". [31, p.67].

The Researcher-in-Residence model is being developed as an attempt to solve the problem of the gap between theory and practice by increasing the practical value of scientific research. Thus, for modern academic knowledge, the formats that allow combining theory with practice, conceptualization with formalization, and a professional's practical contribution to a selected subject field are of great interest. It is especially true for those areas associated with the creative industries' sphere and which exist "at the junction" with creative professions. In the article, we do not focus on the definitions of the spheres of art and design since the formats and principles of education that we describe are relevant for both as well as for the creative industries in general. For this reason, when labeling the options "artist/designer", we mean, first of all, the format "an artist and a designer" in the space of standard discursive and project practices.

The Project Teaching Method in Art and Design Education: a Brief Background

Today, there is an intensification of interaction between artistic and academic environments, at the "junction" of which new educational strategies in art and design are being formed. However, an integration of the formats of art and research residencies into the educational process is being implemented quite actively. In contrast, the practice-based postgraduate study[1] format still causes mistrust among some parts of the academic community even though this educational platform has existed in world practice for several years. Contrary to ambiguous assessments, in recent years, more and more graduate schools worldwide are starting practice-based programs, which are called differently in various national contexts and academic traditions (Ph.D. by Practice, Practice-based research, Practice-led research, etc.).

It seems to us that this is primarily due to the specifics of artists and designers' activities, which at its core has an intellectual-research and a subjectpractical component. Also, it is closely associated with the development of society and culture with their constant request to reformat the socio-material environment. From an artist and a designer, society expects timely answers to topical questions and mastery of conceptualization and "materialization" procedures, and the practice of finding concrete designs for concepts. In short, artists and designers' activities aim to provide new "situational assemblies" in various areas - from urban planning to everyday behavioral practices.

The practical orientation of training in art and design in most cases involves working on a specific project or projects. As is commonly believed, the project-based teaching method dates back to the $16^{\text {th }}-17^{\text {th }}$ centuries: in Europe, it was used in architectural schools, mainly in Italy and France [23, pp.155171]. Thus, in the Roman Academy of Arts, progetti, i. e., projects, were created. As N. Netesova notes, referring to B. Valyasek, "their fundamental features were: focus on students (since their work was independent); focus on reality (practical problems were the 
subject of work); focus on the final product (a plan, a sketch, a model were developed)" [5, pp.587-590]. In the $18^{\text {th }}-19^{\text {th }}$ centuries, the project method spread to other European countries and began to be used in the United States [19, pp.307-318, revised version]. At the beginning of the $20^{\text {th }}$ century, original models of art-industrial universities were created based on the VKHUTEMAS in the USSR and the Bauhaus in Germany. They had no analogs in the past, and they set the development logic for further education in the fields of art and design. Practical orientation and relevance either in production, trade, etc., or in the social sphere (sometimes in both areas, for example, in the case of projects related to social advertising, waste-free production, etc.) became mandatory for these areas. Subsequently, education in creative industries continued to focus on the market and society's needs. Back in the middle of the last century, this fact was noted by one of the most significant figures of English design, Misha Black - an architect, teacher, Professor of industrial design at the Royal College of Art of Great Britain. He believed that a designer must possess several specific competencies, be a good analyst and understand production conditions. Otherwise, "their assessment of the needs of society will be far from the requirements of technology and production capabilities; it will immortalize the opinion that a designer is a decorator whose task is only to gild mass production for the sake of fashion" [1, p.9-11]. Based on the Royal College of Art program, designer training programs were created. Afterward, they were applied in other higher educational institutions in the UK, for example, at the University of Leeds, which is now known for its industrial designer training program. In their article Models of Design Education: Foreign Experience, E. Koveshnikova and N. Koveshnikova comment on this fact: "The University of Leeds has extensive experience in this interdisciplinary approach to teaching the profession. All of its staff are either experienced industrial designers or highly qualified scientists conducting scientific research in the field. The university's long-standing ties with industrial firms ensure that the knowledge and professional skills acquired by students during their studies fully meet the expectations of potential employers" [2]. The situation is similar in most higher educational institutions that train future artists and designers: in addition to studying theoretical disciplines, working in a workshop or studio, students also work on their projects (from which students' portfolios are formed dur- ing their studies). In many educational institutions, the task is to quickly integrate the student with the world of art and design; art critics, art market experts, leading specialists in the relevant field, representatives of various companies, and others are often invited to project presentations. Besides, students must work on their scientific research. Thus, within the framework of the master's course at Academia Italiana (a well-known educational institution that trains specialists from the creative industries), a student must complete a master's thesis - original research conducted at a high scientific level.

It is characteristic that mainly designers and artists[2] themselves have been in charge of creating models of art and design education, as well as constructions - both theoretical and practical, designed to institutionalize design and art in the academic environment. They are forced to deal with the stereotypical perception of art and design as "decoration" (as Black wrote about). For a long time, society and the Academy of Arts refused to recognize the intellectual, exploratory nature of contemporary art and design practices, seeing an artist or a designer as a simple performer who fulfills an order. Curiously, Ken Garland's classic manifesto First Things First (1964), which is an outstanding example of self-reflection, clearly formulated the need to stop serving the interests of the market and turn to social engineering (that is, a requirement to move from the concept of "making without thinking" to critical reflection and "creation" was formulated). It served as the basis for the emergence of an independent direction within the framework of modern design - social design, which deals with solving complex socio-technical problems: from organizing medical institutions' work to creating innovative educational resources. In addition to social design, there are many other areas in art and design where an artist or designer acts as a researcher - and, like any researcher, he or she needs integrative competencies. It is this task that the format of practicebased postgraduate study, which has increasingly become the subject of discussion in the academic environment in Europe in the past two decades, is designed to solve.

On September 20, 2019, the HSE Art and Design School hosted a round table, "Education in the Field of Art and Design: Formats and Perspectives", initiated by HSE Doctoral School of Art and Design with the participation of J. Terney, E. Skjold, T. Rivchun, L. Alyabyeva, T. Fadeeva, A. Staruseva-Persheeva, 


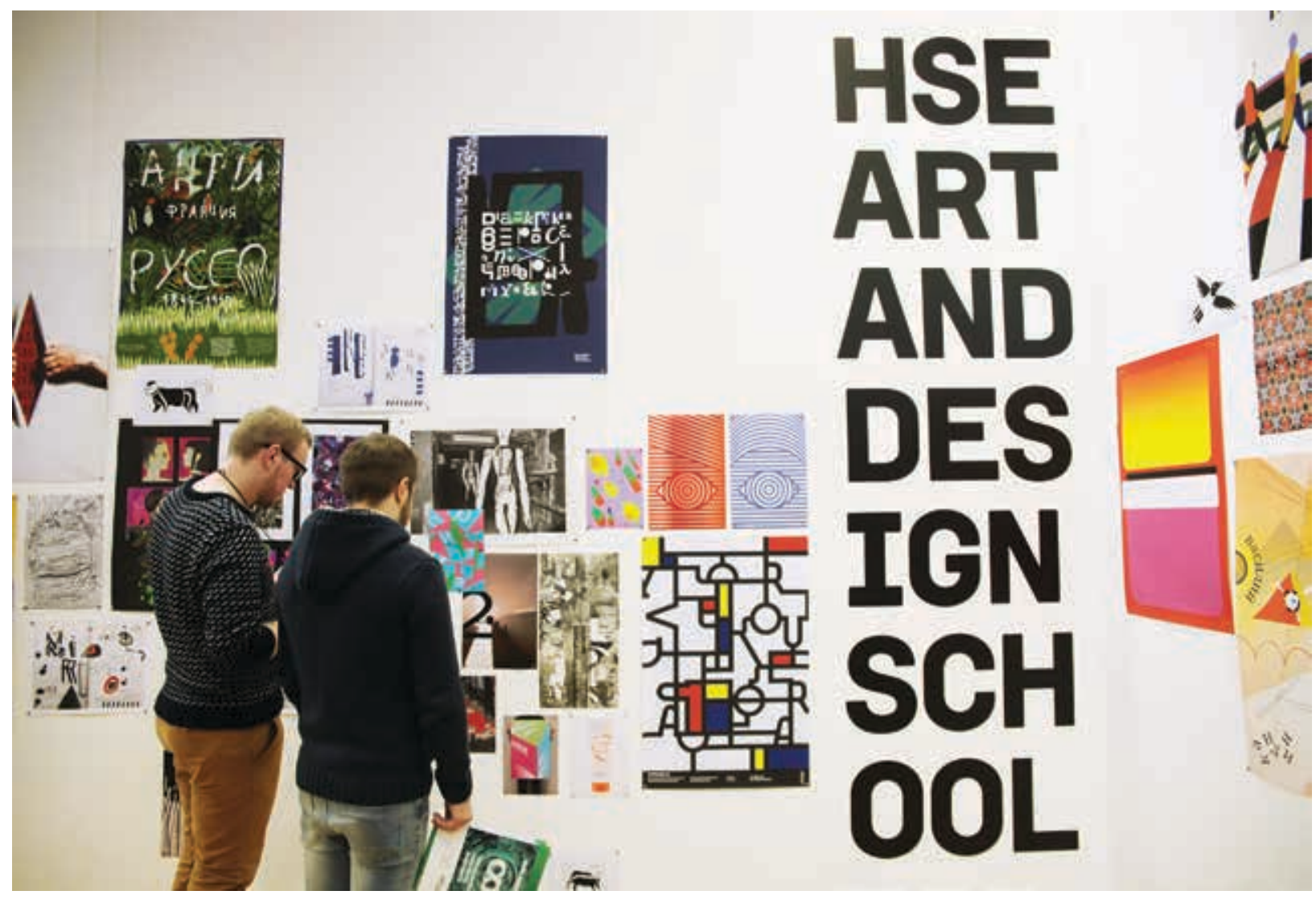

IIl. 1. HSE Art and Design School, 2020

I. Moorer, I. Sirotkina, and others. Within the round table framework [4], the project method in art and design education, including postgraduate studies, was discussed. The round table participants talked about various formats of the "synthesis" of practice and theory within their postgraduate schools' framework (these formats will be discussed below). In addition, in the speeches of J. Terney, I. Moorer, E. Skjold, and others, the topic of the growing interest on the part of artists and designers (practitioners) in academic learning formats, including the Ph.D., was raised. It was noted that the interest of practitioners in academic research work is due to the fact that postgraduate studies allow them to structure existing knowledge better and master their subject area at a higher level of conceptual structural organization, to find possible directions for further development, taking into account the artistic context and their own space of activity. Often, practitioners have a need, for one reason or another, to conceptualize and verbalize the accumulated practical knowledge. A methodological toolkit that is being formed today can also help them with this. In addition, the conjugation of theoretical and practical knowledge can give rise to such "insights" (ideas, approaches, solutions) that could not arise in a nar- row space of professional expertise or within the boundaries of a studio or workshop. Reflections on the specifics of this approach were discussed within the framework of the round table "Education in the Field of Art and Design: Formats and Perspectives", and the "thinking through making" approach (correlating with R. Revans's "action learning" approach) can be found in S. Biye [see: 8]. He focuses on "mimetic learning", noting that knowledge's interiorization occurs mainly through bodily practices, including imitation, embodied knowledge. In her article Knowing Through Making: The Role of the Artefact in Practice-led Research, Maarit Mäkelä goes further, focusing on the research potential of theory and practice interaction rather than on teaching practices and knowledge transfer.

Mäkelä examines the situation in Finland in the late 2000s when artists and designers became actively involved in contextualizing and interpreting the creative process and works of art. The emergence of a new type of research project, the obligatory part of which is a work of art or design now, is noted. The central methodological question of this new area of research, according to Mäkelä, is as follows: how can the practical component in art or design interact with the research component in such 
a way as to jointly produce new knowledge, create new approaches to the study of existing problems, represent new methods of solving existing problems? Mäkelä considers art and design works and the process of their creation as an integral part of a research project: they can be regarded as answers to specific research questions, as well as a set of arguments. As an object created by an artist-researcher (or designer-researcher), an artifact can also be seen as a method of collecting and storing information and transmitting it. Nevertheless, artifacts cannot exist separately from the text since contextualization is necessary for their actualization (artifacts must be explained - integrated into a specific context). Thus, the most crucial task of practice-based research is to give "the right to vote" to an artifact: to interpret it, place it in a proper theoretical context, revealing the meanings and values that it embodies [22, pp.157-163].

\section{Practice-based Postgraduate Study: Foreign Experience}

Why does an artist need a Ph.D.? To answer this question, let us turn to the experience of European educational institutions. It is well known that many contemporary artists and designers have bachelor's degrees (and some also master's degrees) obtained by them, for example, at Yale or Princeton, since today almost all the largest universities in Europe and the United States have educational programs "Art" and "Design". Among them: Yale University (USA) (School of Art); Princeton University (USA) (Program in Visual Arts, Department of Art and Archeology); Stanford University (USA) (Stanford Department of Art and Art History); the University of Oxford (UK) (The Ruskin School of Art), University of Cambridge (UK) (Cambridge School of Visual \& Performing Arts). There are also universities in other countries, which will be discussed below, including universities in the Nordic countries. These educational programs combine both theoretical blocks and subject-practical ones and include compulsory project work. Graduates of these programs (BA and MA, bachelors and masters) look for an opportunity to continue their professional development in the scientific and academic environment. And a practice-based postgraduate course that combines project and research tracks provides them this opportunity.

In addition to traditional research programs, there are various postgraduate education programs that have multiple modifications in different countries and depend on the chosen field of scientific knowl- edge. Thus, awarding a Ph.D. for the result of an outstanding practical activity (for example, Ph.D. by Practice) is a common practice in art and design. However, there are also Ph.D. by Practice programs in other areas (economics, management, etc.), such as the Ph.D. by Practice-Based Research (PBR) at the School of Business and Law at Swinburne University of Technology (Australia). There is a whole cluster of practice-based Ph. D. Projects offered by one or more universities; a university or universities usually fund them, sometimes with third-party funding. This practice is especially developed in Great Britain (King's College London, University of Oxford, and others)[3].

Let us return to the discussion of practice-based graduate programs in the fields of art and design. As we have seen, there is a wide variety of such postgraduate programs in the UK. Ph.D. degrees can be obtained through traditional research tracks and can be awarded based on an outstanding publication or as a result of outstanding practice. Among the universities that implement practice-oriented research programs in the fields of art and design in the UK, there are: Kingston University, London (Practice-based Ph.D.) [18], the University of Westminster, London (ADAPT-r / Ph.D. by Practice) [34], University of East Anglia, Norfolk (Ph.D. by Professional Practice (Creative/Critical)) [33] and others. Also, there are Ph.D. Art and Ph. D. Design programs [15, pp.82-91], which managed to establish themselves within the British Academy framework. By default, these programs are practiced-oriented and are usually taught to artists and designers who already have an outstanding portfolio. For example, in Goldsmiths (University of London), in the MPhil/ Ph.D. Art direction, three different training tracks are offered: Thesis by Practice, Thesis by Practice and Written Dissertation, and Thesis by Written Dissertation. Most often, a research project, implemented with the involvement of practice, consists of two components: an artifact (or another result of practical activity) and a textual part, usually called exegesis. Exegesis (from Greek: "deduction") is "clarification", "interpretation". The exegesis aims at revealing the meaning embedded by the author in the text as accurately as possible. Along with the interpretation of secular texts, there is also biblical exegesis. However, recently this term has been used in connection with the methodology of scientific research. For example, on the Edith Cowan University Western Australia (ECU) website, you can read about the 
practice of exegesis being used as a methodological procedure: "The ECU guidelines for a Ph.D. or Masters by Research creative project describes the written exegesis as 'supporting, contextualising and/ or amplifying the creative project'. The exegesis is a multifaceted document that is intended to show your understanding of 'previous material in the relevant field of inquiry or creative arts genre', a 'thorough understanding of the conceptual, theoretical and/or cultural context' of the discipline', and 'how the research is a substantial and original contribution to knowledge."' [13].

Since the practice-based postgraduate study format has not yet received a clear structural organization, recognized universally, and is the subject of academic discussion, there is a methodological commentary on almost every corresponding postgraduate program. For example, Kingston University's page for the practical design-based graduate program provides a breakdown of what is meant by "practice" and how practice and theory interact: "The practice may be in any field, for instance, fine art, art history, curating, design, engineering and technology, architecture, creative writing, musical composition, film, dance, and performance. For such a research project, the thesis should reflect a coherent research process, demonstrate a critical appreciation of the context of the research, its relationship to existing literature/practices and received opinion, and show that the research has produced an original contribution to knowledge.The relationship of this reflective commentary to the other forms of material submitted must be clearly articulated so that the work forms a single coherent body, considered collectively as the thesis." [18]

The Goldsmith's MPhil/Ph.D. art program page, which was discussed above, details the requirements for each of the tracks. The Thesis by Practice format assumes a project (studio, exhibition, and so on), project documentation, and research text $(20,000-$ 40,000 words for Ph.D., 10,000-20,000 for MPhil). "Thesis by Practice and Written Dissertation" includes the project part, as well as the text of the research (40,000-80,000 words for Ph.D., 20,00040,000 for MPhil). Finally, "Thesis by Written Dissertation" is a "traditional" track and involves writing a dissertation text $(80,000-100,000$ words for Ph.D., 40,000-50,000 for MPhil). Note that with all the variety of programs, one thing remains unchanged: the presence of a mandatory text part along with a project/artifact.
The search for vocabulary, clarification of the basic concepts, numerous discussions around the format, and different variations of names contribute to the establishment of boundaries and consolidation of the structure of the format, the so-called "crystallization". Once again, we note that in all the programs under consideration, the role of the dissertation research itself is emphasized - a text that is conceptually significant for scientific discourse, which a degree seeker should prepare (even "Thesis by Practice" implies writing a text at a high scientific level with the designation of the goals, objectives of the research, its novelty, methodology, etc.). For a traditional research track, the text volume is approximately 80,000 words (usually up to 100,000 ); for practice-oriented postgraduate programs, the volume is half that $-40,000$ words (up to 50,000 ). It is assumed that in this model, the $50: 50$ model, the second $50 \%$ is "practice". The $50: 50$ model is a subject of discussion and criticism. The problem is that "practice" is understood differently in each case, which can be seen by studying, for example, the description of the program on the corresponding page of the Kingston University website, where it is said about practice-based or practice-led research - some researchers use these terms synonymously while others insist that there is a significant difference between them. L. Candy notes that practice-based research is "an original investigation undertaken to gain new knowledge partly through practice and the outcomes of that practice" [11]. That is, the emphasis is on the result of practical activity, and the textual component of the study is intended to contextualize this result. In practice-led research, the focus is on the practice itself, its essence, its specifics. The research is designed to "push" our boundaries of understanding this practice and reveal new knowledge about it. The research focuses on deepening understanding of practice. In a dissertation, practical research results can be fully described in text form without including an artifact (the result of activity).

The term "practice-led research" is covered in detail in the book Practice-led Research, Research-led Practice in the Creative Arts by $\mathrm{H}$. Smith and R. T. Dean [30], which states that artistic work itself is a form of research and forms descriptive research results ("creative work in itself is a form of research and generates detectable research outputs") [30]; that creative practices can lead to specialized research, which can then be summarized and pre- 
sented in manuscript form ("can lead to specialized research insights which can then be generalized and written up as research") [30]. In this respect, the recently published article Creative Practice as Research: Discourse on Methodology by R. L. Skains is of interest. The author comprehends the specifics of artistic practices as research methodologies [29]. It seems to us that various variants of names indicate the renewal of the scientific and methodological language, the search for nominatives behind which there are new meanings, the formation of such a dictionary that would help define the innovative formats that are emerging today in the space of academic knowledge.

Within this study's framework, the Nordic countries' practice-based postgraduate study programs are also of great interest. The situations in these countries are different, as are the approaches to the practice-based postgraduate study format. For example, in Denmark, in addition to working on a project, a graduate student is required to write full-fledged research (about 90,000 words) and go through all the traditional procedures of public defense. In Sweden, the main emphasis is on the practical component, and the volume of the theoretical part of the work can be significantly less than in Denmark - approximately $30,000-40,000$ thousand words; the programs themselves are often practice-based. Thus, the University of Gothenburg (Valand Academy) im- plements the Doctoral Studies in Fine, Applied, and Performing Arts program, designed specifically for practitioners and taking into account the specifics of their activities ("the framework of artistic practice"). On the university website, you can find a series of books and articles on artistic research and more than 50 theses, some of which are practice-based. It should also be noted that over the past decade, the artistic research method has firmly entered the academic environment not only in Sweden but also in other European countries. There is an active discussion of this educational format in the scientific literature (for example, Mäkelä, Dash, Nimkulrat, etc., 2011; Klein, 2017; Vanlee, 2019; Butt, 2019, etc.).

In other countries (besides the UK and Nordic countries, for example, Australia, New Zealand, the USA, etc.), there are also either practice-based postgraduate study formats or postgraduate programs with a practical component. However, in this study, we have focused on those regions and educational institutions where there are an active understanding and institutionalization of these formats, there are discussions around them, the integration of practice, academy and business takes place, and also basic formulations, basic concepts, and principles are discussed, and their "codification" takes place. We are not faced with the task of reflecting the specifics of each region in the context of the issues discussed; we try to show and discuss existing opinions and discussion platforms.

\section{REFERENCES}

1. Black, M. 1964. "The Training of Designer Artists at the Royal College of Art, England, no. 3.

2. Koveshnikova, E. N., Koveshnikova, N. A. 2014. "Models of design-education: foreign experience", Proceedings of Tula State University. Humanities, no. 4-2.

3. Cross, N. 1982. Designerly ways of knowing ("Designerly ways of knowing").

4. Round table "Art and design education: formats and perspectives". School of Design of the National Research University Higher School of Economics. September 20, 2019. [Online]. URL: https://design.hse.ru/ news/1098/ (asses date: 27.06.2020).

5. Netesova, N. I. 2014. "Development of the project method in the system of education", Young Scientist. no. 19 , pp. 587-590.

6. Simon, G. 1969. Science of the Artificial. Moscow.

7. Art \& Education / PhD in Practice, Academy of Fine Arts Vienna / [Online]. URL: https://www.artandeducation.net/announcements/109662/phd-in-practiceacademy-of-fine-arts-vienna/ (asses date: 26.06.2020).
8. Billett, S. 2014. Mimetic learning at work: Learning in the circumstances of practice. Cham, Switzerland: Springer.

9. Candy, L., Edmonds, E. 2018. "Practice-based research in the creative arts: Foundations and Futures from the Front Line", LEONARDO, vol. 51, no. 1.

10. Candy, L. Theory and Practice in Creative Practitioner Research. Unpublished paper based on Keynote Talk to DESIRE2011 conference Eindhoven NL. [Online]. URL: https://www.academia.edu/10331703/Theory_and_ Practice_in_Creative_Practitioner_Research / (asses date: 25.05.2020).

11. Candy, L. Practice Based Research: A Guide. CCS Report: 2006-V1.0 November/ [Online]. URL: https://www. researchgate.net/publication/257944497 (asses date: 27.06.2020).

12. Design Council [Online]. URL: https://www.designcouncil.org.uk/ (asses date: 26.06.2020).

13. Edith Cowan University / Research Methodologies for the Creative Arts \& Humanities: Exegesis. [Online]. URL: https:// ecu.au.libguides.com/c.php?g=410634\&p=2797941 / (asses date: 25.05.2020). 
14. Epstein, R. 2005. "Generativity theory and creativity", M.A. Runco \& R. S. Albert (Eds.), Theories of creativity (Rev. ed.). Cresskill, NJ: Hampton Press. 2005. Pp. 116-140.

15. Hockey, J. 2003. "Practice - Based Research Degree Students in Art and Design: Identity and Adaptation", International Journal of Art \& Design Education. no.22.

16. Ingold, T. 2013. Making: Anthropology, archaeology, art and architecture. Oxon: Routledge.

17. Interview between the JAWS editorial team and Dr Rachel Hann // Journal of Arts Writing by Students, vol. 5, no. 1, 1 March. 2019.

18. Kingston University, London. [Online]. URL: https:// www.kingston.ac.uk/research/research-degrees/ available-degrees/practice-based-phd/ (asses date: 25.05.2020).

19. Knoll. M. 1995. Progressive Education Across the Continents. A Handbook, ed. Hermann Röhrs and Volker Lenhart. New York: Lang.

20. Lawson, B. 2005. How Designers Think - The Design Process Demystified. University Press, Cambridge.

21. Lithgow, M., Wall, K. 2017. Embedded Aesthetics: Artistin-Residencies as Sites of Discursive Struggle and Social Innovation. Seismopolite 19. [Online]. URL: http:// www.seismopolite.com/embedded-aesthetics-artist-inresidencies-as-sites-of-discursive-struggle-and-socialinnovation (asses date: 25.05.2020).

22. Mäkelä, M. Knowing Through Making: The Role of the Artefact in Practice-led Research. Knowledge and Policy, 20(3):157-163. October 2007. [Online]. URL: https:// www.researchgate.net/publication/227320305_Knowing_Through_Making_The_Role_of_the_Artefact_in_ Practice-led_Research / (asses date: 27.06.2020).
23. Pecore, J. 2015. "From Kilpatrick's Project Method to Project-Based Learning", International Handbook of Progressive Education.

24. PhDArts / Individual Projects / Resonances between Dance and Gnosis [Online]. URL: https://www.phdarts. eu/ResonancesbetweenDanceandGnosis / (asses date: 26.06.2020).

25. PhDArts, international doctorate programme in art and design, is a collaboration between Leiden University Academy of Creative and Performing Arts and the Royal Academy of Art (KABK) in The Hague / Requirements. [Online]. URL: https://www.phdarts.eu/Admission/Requirements / (asses date: 26.06.2020).

26. Rust, C., Mottram, J., Till, J. 2007. "AHRC Research Review: Practice-Led Research", Art, Design and Architecture.

27. Research Pavilion \#3 Venice 2019. [Online]. URL: http:// www.researchpavilion.fi/ (asses date: 26.06.2020).

28. Schön, D. A. The reflective practitioner: how professionals think in action, Basic Books: New York. 1983.

29. Skains, R. L. 2018. Creative Practice as Research: Discourse on Methodology. 19:1, 82-97. [Online]. URL: https://www.tandfonline.com/doi/full/10.1080/14682 753.2017.1362175

30. Harvey, A. (2017). Art and Design. Critical Survey, 29(1), 133-137. DOI:10.2307/26382293

31. Bigelow, Florence M. "General Principle of Art and Design." Fine Arts Journal 31, no. 6 (1914): 572-85. Accessed March 22, 2021. DOI:10.2307/25603464

32. Seago, A., \& Dunne, A. (1999). New Methodologies in Art and Design Research: The Object as Discourse. Design Issues, 15(2), 11-17. DOI:10.2307/1511838 
Людмила Анатольевна Алябьева

кандидат филологических наук, доцент Факультета коммуникаций, медиа и дизайна НИУ ВШЭ,

Академический директор Аспирантской школы по искусству и дизайну

e-mail: lalyabieva@hse.ru

Москва, Россия

ORCID 0000-0001-7795-2059

ResearcherID Z-1306-2019

Ирина Михайловна Сахно

доктор филологических наук, профессор кафедры теории и истории культуры RUDN UNIVERSITY, Академический руководитель магистерской программы «Практики современного искусства» Факультета коммуникаций, медиа и дизайна, Школы дизайна НИУ ВШЭ e-mail: sakhno_im@pfur.ru

Москва, Россия

ORCID 0000-0002-5510-6684

ResearcherID B-2047-2016

Scopus Author ID 57196349789

Татьяна Евгеньева Фадеева кандидат искусствоведения, доцент Факультета коммуникаций, медиа и дизайна НИУ ВШЭ e-mail: tfadeeva@hse.ru

Москва, Россия

ORCID 0000-0002-6754-4235

ResearcherID Z-2521-2019

\section{ИННОВАЦИОННЫЕ ОБРАЗОВАТЕЛЬНЫЕ ФОРМАТЫ В СФЕРЕ ИСКУССТВА И ДИЗАЙНА: СОСТОЯНИЕ И ПЕРСПЕКТИВЫ}

\footnotetext{
Аннотация: В центре внимания авторов статьи новейшие образовательные технологии и форматы в сфере искусства и дизайна, среди которых наиболее перспективными являются различные практикоориентированные аспирантуры. Сегодня, по мнению авторов, традиционные образовательные программы не отвечают потребностям smart-общества, в котором доминируют информация, технологии и креативность. Новые форматы аспирантских программ призваны актуализировать профессиональную направленность обучения, сформировать синтез теории и практики, установив принципы конвергентного образования. Задача инновационных образовательных программ в закреплении исследовательских и практических / прикладных навыков, в соединении теоретических наработок и практических форм их репрезентации. Авторы размышляют о том, как меняются образовательные и академические стандарты в условиях возрастающего интереса к проектным формам и практическим
}

исследованиям, анализируют предысторию формирования проектных сфер деятельности в арт- и дизайнобразовании. Скрупулёзное изучение международного опыта и анализ программ аспирантских европейских школ в сфере искусства и дизайна позволяют им сделать обобщения и подробно рассмотреть такой трек аспирантуры, как PhD в формате практических исследований. Сегодня в условиях диверсификации моделей аспирантской подготовки и расширения образовательных моделей привычная аспирантская классификация «преподаватель-исследователь», по мнению авторов статьи, уже устарела. Практико-ориентированные бакалаврские и магистерские программы в области искусства и дизайна, которые становятся важным ресурсом для открытия инновационных аспирантских программ, ориентированы на прикладные исследования, эффективность реализации которых является неоспоримым фактом. Формат практико-ориентированной аспирантуры сегодня является предметом академических 
дискуссий и свидетельствует о переформатировании прежних представлений о стандартах послевузовского обучения. В пространстве образовательных и академических моделей обучения сегодня аннулируется дихотомия теории и практики, а практические исследования объединяют методологию научных и практических результатов. Важнейшим инструментом развития интегративной методологии становятся разные кейсы практических исследований, эффективность реализации которых во многом зависит от установки руководства образовательного учреждения на обновление класси-

\section{Постановка проблемы}

Недостаточная консолидация академического сообщества по проблеме практикоориентированных магистерских и аспирантских программ существует в том числе и из-за устаревшей модели образования, долгое время не подвергавшейся ревизии. Практика как таковая до недавнего времени не считалась для академических научных стандартов приоритетным форматом обучения, а практические навыки формировались учреждениями среднего профессионального образования. Интерес у исследователей-теоретиков к практическим проектам возникал в основном тогда, когда они изучали некий корпус произведений и формулировали закономерные вопросы: «Как это сделано? С какой целью? В каких культурно-исторических реалиях появился артефакт?». Ответы требовали апелляции к формату практических исследований. Современные образовательные технологии позволяют сегодня по-новому организовать учебный процесс в высшей школе и актуализировать профессиональную направленность обучающихся. Новые форматы PhD могут стать, на наш взгляд, той инновационной образовательной платформой, которая позволит реализовать не только обязательные компоненты профессионально-ориентированного обучения в высшей школе, но и развить креативные и интегративные компетенции, необходимые в условиях меняющегося мира. Нам хотелось бы отрефлексировать дискуссионные проблемы и предложить своё видение проблемы практико-ориентированных аспирантур. Совершенно очевидно, что прежняя образовательная модель не отвечает требованиям подготовки высококлассного специалиста с многопрофильными компетенциями, способного не только теоретически осмыслить исследовательскую проблему, но и предложить инновационный инструментарий реализации проектных решений. ческих образовательных форматов. В статье представлен краткий обзор основных дискуссионных платформ по проблемам практико-ориентированных аспирантских программ, в научный оборот вводится большой пласт иноязычных источников, в которых исследуются зарождающийся феномен и разнообразные модели практических исследований.

Ключевые слова: аспирантура, PhD by Practice, ucкусство, Art PhD, дизайн, практические исследования, Practice-based research, Practice-led research.

Почему? Во-первых, сегодня изменилось представление о том, кто такой современный художник, и в чём заключается суть его творчества. Долгое время теоретики склонны были видеть в художнике Демиурга-творца, который не понимает закодированные смыслы произведения, и потому ему нужен интерпретатор-искусствовед, который включает творческое наследие художника в соответствующий контекст. Однако современные художники сегодня работают на очень высоком интеллектуальном и концептуальном уровне, что находит отражение как в создаваемых ими произведениях, так и в сопровождающих их рефлексиях (с учётом существующих «фреймов», контекстов и парадигм). Сегодня художники и дизайнеры идут в академии художеств за тем, чтобы получить новые инструменты работы с материалом. Для многих художников и дизайнеров возможность осмыслить свою практику на системном уровне, предоставляемая академией, служит «триггером» для рефлексии и помогает сформировать траекторию дальнейшего движения в профессиональном предметном поле.

Во-вторых, теоретики всё чаще обращаются к работе с материалом, к фактуре и деланию (thinking through making) [16, с. 11], двигаясь от абстрактных построений к полевым исследованиям. Многие начинают с «ментальных экспериментов» и переходят к непосредственной их реализации. Например, исследователь в области Game studies может интересоваться вопросом, что будет, если создать некую «анти-игру», в которой отсутствует то, что делает игру игрой. Возникает вполне правомерный вопрос, будет ли это игра, как это может выглядеть, как это повлияет на наше понимание игры. Впоследствии он может создать модель такой игры и попытаться реализовать свои гипотезы на практике, самостоятельно или в рамках исследовательской группы. В нашей работе мы приведём примеры 
нескольких подобных «кейсов». Необходимо добавить, что «теоретики» и «практики», интегрируя в свою деятельность и в практику, и в теорию, сталкиваются с непростыми методологическими вызовами и должны, по сути, выполнить «двойную работу». Так, по результатам обучения в практико-ориентированной аспирантуре соискатель научной степени обязан не только написать научную работу, но и реализовать проект, внося таким образом не только теоретический, но и практический вклад в соответствующую предметную область.

В контексте данного исследования большой интерес представляет также формат исследовательской резиденции, который возникает как «симметричный ответ» уже давно существующему формату художественной резиденции, «артрезиденции» (модель «Artist-in-Residence», «AiR»). Художественная резиденция - место аккумуляции творческих сил художников и дизайнеров. Существует множество различных вариантов подобных резиденций. Художественные стратегии варьируются от резиденции к резиденции - в некоторых акцент делается на командной работе над конкретным проектом в производственных мастерских, другие предполагают создание самостоятельных проектов «с нуля» и т. д. Художественные резиденции обычно реализуются на базе различных институций (от музеев и галерей до дирекций по управлению городскими парками и скверами), в том числе и научных. Например, в Великобритании существует давняя традиция интеграции практикующих художников в академии художеств («Artist-in-residence programs»). М. Литгоу и К. Уолл в статье «Включая эстетику: художественная резиденция как пространство дискурсивной борьбы и социальных инноваций» справедливо замечают: «Художественные резиденции дают каждому художнику пространство для эксперимента, обучения и творчества, способствуя социальному взаимодействию, диалогу и/или сотрудничеству между коллегами и представителями разных профессий и дисциплин» [21].

Помимо формата «Artist-in-Residence» в настоящий момент также наблюдается активное развитие формата «Researcher-in-Residence», связанное с тем, что большинство учёных хотели бы, чтобы их исследования оказывали большее влияние на практику. Ещё в 1983 году Д. Шон отмечал, что налицо проблема недостаточной интеграции теории и практики: «В последние годы становится всё очевиднее, что учёные, которые должны транслировать профессиональному сообществу полезные знания, всё реже способны сказать что-то, что представляет ценность для практиков» [28, р с. 10]. В своём выступлении на конференции DESIRE2011 в Эйндховене Линда Кэнди отметила важный фактор: «Между теорией, применяемой на практике, <...> и теорией, выводимой из практики, существует огромная разница. Творческая практика не ограничивается переработкой накопленных теоретических знаний: она предполагает создание нового экспериментальным и аналитическим путём, а этот процесс, в свою очередь, позволяет понять, что хорошо работает на практике» [10]. Ссылаясь на высказывания Г. Салливана, она рассуждает о перспективах подобного подхода: «Как отмечает Грэм Салливан, благодаря практике, сопровождающейся рефлексией, как методу решения задач, который включает в себя циклический процесс обучения в ходе выполнения конкретных действий, мы можем осознать недостатки существующих подходов к поиску решений» [31, с. 67].

Модель «Researcher-in-Residence» разрабатывается как попытка решения проблемы разрыва теории и практики путём повышения практической значимости научных исследований. Таким образом, для современных академических знаний большой интерес представляют форматы, позволяющие объединить теорию с практикой, концептуализацию с формализацией и практическим вкладом профессионала в избранное предметное поле. Особенно это характерно для тех областей, которые связаны со сферой креативных индустрий и существуют «на стыке» с творческими профессиями. В данной статье мы не делаем акцент на дефинициях сфер искусства и дизайна, поскольку описываемые нами форматы и принципы обучения актуальны и для того, и для другого, как и в целом для сферы креативных индустрий. По этой причине, маркируя опции «художник / «дизайнер», мы подразумеваем прежде всего формат «художник и дизайнер» в пространстве единых дискурсивных и проектных практик.

Проектный метод обучения в арт- и дизайнобразовании: краткая предыстория

Сегодня наблюдается интенсификация взаимодействия художественных и академических сред, на «стыке» которых формируются новые образовательные стратегии в сфере искусства 
и дизайна. Однако, если интеграция форматов художественной и исследовательской резиденций в образовательный процесс реализуется довольно активно, то формат практико-ориентированной аспирантуры ${ }^{1}$ по-прежнему вызывает недоверие у некоторой части академического сообщества, несмотря на то, что эта образовательная платформа в мировой практике существует уже не первый год. Вопреки неоднозначным оценкам, в последние годы всё больше аспирантских школ по всему миру открывают практико-ориентированные программы, которые в разных национальных контекстах и академических традициях именуются по-разному (PhD by Practice, Practice-based research, Practice-led research и др.).

Нам представляется, что во многом это связано со спецификой деятельности художников и дизайнеров, которая в своей основе имеет как интеллектуально-исследовательскую, так и предметно-практическую составляющую, и тесно сопряжена с развитием общества и культуры, с постоянным запросом с их стороны на переформатирование социоматериальной среды. Общество ожидает от художника и дизайнера своевременных ответов на актуальные вопросы и владения процедурами как концептуализации, так и «материализации», и практикой воплощения концептов в конкретные решения. Одним словом, деятельность художников и дизайнеров призвана обеспечивать новые «ситуационные сборки» в самых разных сферах - от градостроительства до повседневных поведенческих практик.

Практическая ориентированность обучения в сферах искусства и дизайна в большинстве случаев предполагает работу над конкретным проектом/проектами. Проектный метод обучения, как принято считать, восходит к XVI-XVII вв.: в Европе он использовался в архитектурных школах, преимущественно в Италии и Франции [23, с. 155-171]. Так, в Римской академии искусств создавались работы-progetti, т.е. проекты. Как отмечает Н. Нетесова, ссылаясь на Б. Валясэка, «их фундаментальными признаками были: ориентация на учащихся (так как их работа была самостоятельной); ориентация на действительность (предметом работы служили практические проблемы); ориентация на конечный продукт (разрабатывались план, эскиз, модель)» [5, с. 587-590]. В XVIII-

1. Аспирантура в РФ согласно действующему законодательству является третьей ступенью высшего образования и, соответственно, частью образовательного процесса.
XIX веках проектный метод распространяется на другие страны Европы и начинает использоваться в США [19, с. 307-318, revised version]. В начале XX столетия на базе ВХУТЕМАСа в СССР и Баухауса в Германии были созданы оригинальные, не имевшие аналогов в прошлом модели художественно-промышленных вузов, которые задали логику развития дальнейшего образования в сферах искусства и дизайна. Обязательной для этих сфер стала практическая ориентированность и востребованность либо в сферах производства, торговли и пр., либо в социальной сфере (иногда - и там, и там, например, в случае проектов, связанных с социальной рекламой, безотходным производством и пр.). В дальнейшем образование в сферах креативных индустрий продолжило ориентироваться на рынок и запросы общества. Этот факт отмечал ещё в середине прошлого века один из крупнейших деятелей английского дизайна, архитектор, педагог, профессор индустриального дизайна Королевского колледжа искусств Великобритании Миша Блэк. Он полагал, что дизайнер обязан владеть рядом специфических компетенций, быть хорошим аналитиком и разбираться в условиях производства, иначе «его оценка потребностей общества будет далека от требований технологий и возможностей производства, что увековечит мнения о дизайнере как о декораторе, задача которого состоит лишь в том, чтобы наносить позолоту на массовую продукцию в угоду моде» [1, с. 9-11]. На базе программы Королевского колледжа искусств создавались программы подготовки дизайнеров, которые затем применялись и в других высших учебных заведениях Великобритании, например, в университете Лидса, который сегодня известен своей программой подготовки промышленных дизайнеров. Ковешникова Е.Н. и Ковешникова Н.А. в своей статье «Модели дизайн-образования: зарубежный опыт» комментируют этот факт: «Университет Лидса имеет богатый опыт такого междисциплинарного подхода к преподаванию профессии. Все его сотрудники являются либо опытными промышленными дизайнерами, либо высококлассными учёными, проводящими научные исследования в данной области. Давние связи университета с промышленными фирмами гарантируют, что знания и профессиональные навыки, полученные студентами во время обучения, полностью соответствуют ожиданиям потенциальных работодателей» [2]. Аналогичным образом ситуация об- 
стоит в большинстве высших учебных заведений, осуществляющих обучение будущих художников и дизайнеров, - помимо изучения теоретических дисциплин, работы в мастерской или студии, студенты также трудятся над собственными проектами (из которых за время обучения студента формируется его портфолио). Во многих учебных заведениях ставится задача скорейшей интеграции студента с миром искусства/дизайна, нередко на показы проектов приглашаются художественные критики, эксперты арт-рынка, ведущие специалисты в соответствующей области, представители различных компаний и т.д. Помимо этого, студенты должны работать над собственными научными исследованиями. Так, в рамках магистерского курса в Academia Italiana (известное учебное учреждение, занимающееся подготовкой специалистов из сферы креативных индустрий) студент обязан выполнить магистерскую диссертацию - оригинальное исследование, проведённое на высоком научном уровне.

Характерно, что созданием моделей арт-и дизайн-образования, а также конструкций - как теоретических, так и практических, призванных институционализировать дизайн и искусство в академической среде, - занимались (и в большинстве своём продолжают заниматься) преимущественно сами дизайнеры и художники ${ }^{2}$. Они вынуждены иметь дело со стереотипным восприятием искусства и дизайна как «украшательства» (о чём писал ещё Блэк). Общество и академии художеств довольно долго отказывались признавать интеллектуальный, исследовательский характер современных художественных и дизайнерских практик, видя в художнике и дизайнере простого исполнителя, выполняющего заказ. Любопытно, что в классическом манифесте Кена Гарланда «First things first» (1964), являющегося выдающимся примером саморефлексии, была чётко сформулирована необходимость прекращения обслуживания интересов рынка и обращения к социальной инженерии (т.е. сформулировано требование перехода от концепции «making without thinking» к критической рефлексии и «созиданию»). Это послужило почвой для возникновения самостоятельного направления в рамках современного дизайна - социального дизайна,

2. Например, именно художники были назначены ректорами ВХУТЕМАСа-ВХУТЕИНа (Е. Равдель, В. Фаворский), они создавали образовательные стандарты и программы, общую образовательную концепцию и «дорожную карту». который занимается решением сложных социотехнических задач: от организации работы медицинских учреждений до создания инновационных образовательных ресурсов. Помимо социального дизайна, существует множество других направлений в искусстве и дизайне, где художник или дизайнер выступает как исследователь - и, как любому исследователю, ему необходимы интегративные компетенции. Именно эту задачу призван решить формат практико-ориентированной аспирантуры, который в последние два десятилетия всё чаще становится предметом обсуждения в академической среде в Европе.

20 сентября 2019 года в Школе дизайна НИУ ВШЭ (HSE Art and Design School) прошёл круглый стол «Образование в области искусства и дизайна: форматы и перспективы», инициированный Аспирантской школой по искусству и дизайну НИУ ВШЭ (HSE Doctoral School of Art and Design), с участием Дж. Терни, Э. Скьолд, Т. Ривчун, Л. Алябьевой, Т. Фадеевой, А. Старусевой-Першеевой, И. Мурера, И. Сироткиной и др. В рамках круглого стола [4] обсуждался проектный метод в арт- и дизайнобразовании, в том числе и в аспирантуре. Участники круглого стола рассказывали о различных форматах «синтеза» практики и теории в рамках своих аспирантских школ (данные форматы будут рассмотрены ниже). Помимо этого, в выступлениях Дж. Терни, И. Мурера, Э. Скьолд и др. была затронута тема возрастания интереса со стороны художников и дизайнеров (практиков) к академическим форматам обучения, включая уровень Ph D. Отмечалось, что интерес практиков к академической исследовательской работе обуславливается тем, что обучение в аспирантуре позволяет им лучше структурировать уже имеющиеся знания и овладеть своей предметной областью на более высоком уровне концептуальной структурной организации, отыскать возможные направления дальнейшего развития с учётом художественного контекста и собственного пространства деятельности. Зачастую у практиков возникает потребность по той или иной причине концептуализировать и вербализировать накопленное практическое знание - и с этим им также может помочь тот методологический инструментарий, который формируется сегодня. Помимо этого, в сопряжении теоретического и практического знания могут рождаться такие «инсайты» (идеи, подходы, решения), которые не смогли бы возникнуть в узком пространстве профессиональных знаний или 
в границах студии, или мастерской. Размышления о специфике данного подхода, обсуждаемого в рамках круглого стола «Образование в области искусства и дизайна: форматы и перспективы», и подхода «thinking through making» (коррелирующего с подходом «action learning» Р. Реванса) можно найти и у С. Бийе [см.: 8]. Он делает акцент на «mimetic learning» («миметическом обучении»), замечая, что интериоризация знания происходит преимущественно через телесные практики, в том числе подражание, кинестетический опыт (англ. embodied knowledge). Маарит Макела (Maarit Mäkelä) в своей статье «Knowing Through Making: The Role of the Artefact in Practiceled Research» идёт дальше, сосредотачиваясь даже не столько на практиках обучения и передаче знания, сколько на исследовательском потенциале взаимодействия теории и практики.

Макела рассматривает ситуацию, сложившуюся в конце 2000-х годов в Финляндии, когда художники и дизайнеры стали принимать активное участие в контекстуализации и интерпретации творческого процесса и произведений искусства. Отмечается возникновение нового типа исследовательского проекта, обязательной частью которого теперь является произведение искусства или дизайна. Центральный методологический вопрос этой новой области исследований, согласно Макеле, таков: как практическая составляющая в искусстве или дизайне могут взаимодействовать с научноисследовательской составляющей таким образом, чтобы совместно производить новое знание, создавать новые подходы к изучению существующих проблем, репрезентировать новые методы решения существующих задач? Макела рассматривает произведения искусства и дизайна и сам процесс их создания как неотъемлемую часть исследовательского проекта: их можно расценивать как ответы на конкретные вопросы исследования, а также как совокупность аргументов. Как объект, созданный художником-исследователем (или дизайнером-исследователем), артефакт также может рассматриваться как метод сбора и хранения информации и её трансляции. Тем не менее артефакты отдельно от текста не могут существовать, поскольку для их актуализации необходима контекстуализация (артефакты должны быть объяснены - интегрированы в определённый контекст). Таким образом, важнейшая задача практико-ориентированного исследования - дать «право голоса» артефакту: интерпретировать его, поместить его в подходящий теоретический контекст, раскрывая те смыслы и ценности, которые он воплощает [22 с. 157-163].

\section{Практико-ориентированная аспирантура: зарубежный опыт}

Зачем художнику PhD? Для того, чтобы ответить на этот вопрос, обратимся к опыту европейских образовательных институций. Хорошо известен тот факт, что многие современные художники и дизайнеры имеют степень бакалавра (а некоторые - и магистра), полученные ими, например, в Йеле или Принстоне, ведь сегодня практически все крупнейшие университеты Европы и США имеют образовательные программы «Искусство» и «Дизайн». Среди них: Yale University (USA) (School of Art); Princeton University (USA) (Program in Visual Arts, Department of Art and Archaeology); (Oxford's Ruskin School of Art); Stanford University (USA) (Stanford Department of Art and Art History); University of Oxford UK (The Ruskin School of Art), University of Cambridge (UK) (Cambridge School of Visual \& Performing Arts), а также университеты других стран, о которых речь пойдет ниже, в том числе и университеты стран Северной Европы. Данные образовательные программы сочетают в себе как теоретические блоки, так и предметно-практические, и включают обязательную проектную работу. Выпускники этих программ (ВА и МА, бакалавры и магистры) ищут возможность продолжать своё профессиональное развитие в научно-академической среде. И такую возможность предоставляет им практико-ориентированная аспирантура, сочетающая проектный и исследовательский треки.

Помимо традиционных исследовательских программ существуют самые разнообразные программы постдипломного обучения (postgraduate education), которые имеют разнообразные модификации в разных странах, а также зависят от выбранной области научного знания. Так, присуждение степени PhD за результат выдающейся практической деятельности (напр., «PhD by Practice») является распространённой практикой в сфере искусства и дизайна, однако программы «PhD by Practice» существуют и в других сферах (экономика, менеджмент и т.д.), как, напр., «The PhD by Practice Based Research (PBR)» на факультете бизнеса и права в Swinburne University of Technology (Австралия). Существует целый кластер practice-based PhD Projects, которые предлагают 
один или несколько университетов; обычно они финансируются из средств университета(-тов), иногда с привлечением стороннего финансирования. Особенно развита эта практика в Великобритании (King's College London, University of Oxford и т.д.) ${ }^{3}$.

Вернёмся к обсуждению практико-ориентированных аспирантских программ в сферах искусства и дизайна. Как мы уже убедились, в Великобритании такие аспирантские программы отличаются широким разнообразием. Степень PhD может быть получена как через традиционные исследовательские треки, так и может быть присуждена на основании выдающейся публикации или же как результат выдающейся практической деятельности. Среди вузов, реализующих практико-ориентированные исследовательские программы в сферах искусства и дизайна в Великобритании, значатся: Kingston University, London (Practice-based PhD) [18], University of Westminster, London (ADAPT-r/ PhD by Practice) [34], University of East Anglia, Norfolk (PhD by Professional Practice (Creative/Critical)) [33] и др. Кроме этого, существуют программы «PhD Art» и «PhD Design» [15, c. 82-91], успевшие зарекомендовать себя в рамках британской академии. «По умолчанию» такие программы подразумевают практическую ориентированность, и обычно на них обучаются художники и дизайнеры, уже имеющие незаурядное портфолио. Например, в Голдсмите (Goldsmiths, University of London) по направлению MPhil/PhD Art предлагаются три различных трека обучения: Thesis by Practice, Thesis by Practice and Written Dissertation $и$ Thesis by Written Dissertation. Чаще всего исследовательский проект, реализованный с привлечением практической составляющей, состоит из двух компонентов: артефакта (или иного результата практической деятельности) и текстовой части, обычно называемой exegesis. Экзегеза (букв. с греч. «выведение») - «разъяснение», «толкование», и задача экзегета - как можно более точно выявить смысл, вложенный автором в текст. Наряду с толкованием светских текстов существует и библейская экзегеза, но в последнее время этот термин используется в связи с методологией научных исследований. Например, на

3. Так, в King's College London существует проект-программа «Choosing Who Not to Die With AI: AI-enhanced stratification for implanted defibrillators»._- URL: https://www.imagingcdt. com/project/choosing-who-not-to-die-ai-enhanced-riskstratification-for-implanted-defibrillators/ (дата обращения: 01.07.2020). сайте австралийского Университета Эдит Коуэн (Edith Cowan University Western Australia - ECU) можно прочитать о том, что практика экзегезы привлекается в качестве методологической процедуры: «В руководстве по работе над творческими проектами для PhD и магистров (Masters of Research) в Университете Эдит Коуэн отмечено, что письменная экзегеза является теоретическим обоснованием творческого проекта, своеобразным дополненным комментарием. Экзегеза - многогранная работа, в процессе которой соискатель должен продемонстрировать понимание «существующего материала в рамках соответствующего направления исследований или жанра» [13], показать «глубокое осмысление понятийного, теоретического и/или культурного контекста» дисциплины и «исследовательского процесса как значимого и оригинального вклада в систему знаний» [13].

Так как формат практико-ориентированной аспирантуры до сих пор не получил чёткой структурной организации, признанной повсеместно, и является предметом академической дискуссии, то практически к каждой соответствующей аспирантской программе существует методологический комментарий. Например, на странице аспирантской программы, основанной на практическом проектировании, Kingston University даётся расшифровка того, что нужно понимать под «практикой», и как взаимодействуют практика и теория: «Направление практики может быть любым: изобразительное искусство, искусствоведение, кураторское дело, инженерные и технические специальности, архитектура, художественная проза, сочинение музыки, кино, танец, исполнительские искусства. Работа, созданная в рамках подобного исследовательского проекта, должна отражать последовательно выстроенный процесс изучения материала, демонстрировать критический подход к нему, связь содержания с существующим корпусом литературы / набором практик в этой области и общепризнанными принципами, а также свидетельствовать, что результатом исследования стал оригинальный вклад в систему знаний. Следует чётко обозначить связь этого аналитического комментария с другими формами представленного материала, чтобы работа воспринималась как единое целое, все элементы которого и составляют научное исследование» [18]. 
На странице программы MPhil/PhD Art Голдсмита, о которой речь шла выше, подробно рассказывается, какие требования предъявляются к каждому из треков. Формат «Thesis by Practice» предполагает проект (студийный, выставочный и т.д.), документацию к проекту, а также исследовательский текст (20000-40000 слов для PhD, 10000-20000 для MPhill). «Thesis by Practice and Written Dissertation» предполагает проектную часть, а также текст исследования (4000080000 слов для PhD, 20000-40000 для MPhill). Наконец, «Thesis by Written Dissertation» является «традиционным» треком и предполагает написание текста диссертации (80000-100000 слов для PhD, 40 000-50000 для MPhill). Заметим, что при всём многообразии программ одно остается неизменным: наличие обязательной текстовой части наряду с проектом/артефактом.

Поиск вокабуляра, пояснение основных понятий, многочисленные дискуссии вокруг формата, различные вариации названий - всё это способствует установлению границ и закреплению структуры формата, так называемую его «кристаллизацию». Ещё раз отметим, что во всех рассматриваемых программах подчёркивается роль непосредственно диссертационного исследования - концептуально значимого для научного дискурса текста, который должен подготовить соискатель степени (даже «Thesis by Practice» подразумевает написание текста на высоком научном уровне с обозначением целей, задач исследования, его новизны, методологии и т.д.). Для традиционного исследовательского трека объём текста составляет приблизительно 80000 слов (обычно до 100 000), для программ практико-ориентированных аспирантур объём вдвое меньше - 40000 слов (до 50000 ). Предполагается, что в этой модели, «50:50 model», вторые «50\%» приходятся на «практику». Сама модель «50:50» является предметом обсуждений и критики, проблемой также является то, что «практика» в каждом случае понимается по-своему, что можно увидеть, изучив, например, описание программы на соответствующей странице сайта Kingston University, где говорится о «practice-based or practice-led research» - некоторые исследователи используют эти термины как синонимы, другие же настаивают на том, что между ними есть существенная разница. Л. Кэнди отмечает, что исследование, основанное на практике, - «это оригинальное исследование, позволяющее по- лучить новые знания через практику, а также результаты этой практики» [11], т.е. акцент делается на результате практической деятельности, а текстовый компонент исследования призван контекстуализировать этот результат. B practice-led research фокус - на самой практике, её сущности, её специфике, исследование призвано «раздвинуть» наши границы понимания этой практики и выявить новое знание о ней. Основное внимание в исследовании уделяется углублению знаний о практике, в диссертации результаты практических исследований могут быть полностью описаны в текстовой форме без включения артефакта (результата деятельности).

Подробно термин «practice-led research» освещается в книге Х. Смит и Р. Т. Дин «Practice-led research, research-led practice in the creative arts» [30], где утверждается, что художественная работа сама по себе является формой исследования и формирует поддающиеся описанию результаты исследования («creative work in itself is a form of research and generates detectable research outputs») [30], и что креативные практики могут вести к специализированным исследованиям, которые затем могут быть обобщены и представлены в виде рукописи («саn lead to specialised research insights which can then be generalised and written up as research») [30]. В этом отношении интересна и недавно опубликованная статья Р.Л. Скайнс «Creative Practice as Research: Discourse on Methodology», который осмысляет специфику художественных практик как исследовательских методологий [29]. Нам представляется, что различные варианты названий свидетельствуют об обновлении научнометодического языка, о поиске номинативов, за которыми стоят новые смыслы, о формировании такого словаря, который помог бы определить инновационные форматы, складывающиеся сегодня в пространстве академических знаний.

Большой интерес в рамках данного исследования представляют также программы практико-ориентированной аспирантуры, которые существуют в странах Северной Европы. Ситуации в этих странах разные, как и подходы к формату практико-ориентированной аспирантуры. Например, в Дании помимо работы над проектом аспирант обязан написать полноценное исследование (ок. 90000 слов), а также пройти все традиционные процедуры публичной защиты. В Швеции же основной акцент делается на практической составляющей, а объём теорети- 
ческой части работы может быть существенно меньше, чем в Дании, - ок. 30 000-40000 тыс. слов; сами программы зачастую ориентированы на практиков. Так, в университете Гётеборга (Valand Academy) реализуется программа «Doctoral Studies in Fine, Applied and Performing Arts», предназначенная именно для практиков и учитывающая специфику их деятельности («the framework of artistic practice»). На сайте университета можно найти серию книг и статей, посвященных теме «художественного(/арт-) исследования» («artistic research»), а также более 50 диссертаций, часть которых «базируются» на практике («practicebased»). Также необходимо отметить, что метод «artistic research» за последнее десятилетие прочно вошёл в академическую среду не только в Швеции, но и в других странах Европы, ведётся активное обсуждение этого образовательного формата в научной литературе (напр., Mäkelä, Dash, Nimkulrat etc, 2011; Klein, 2017; Vanlee, 2019; Butt, 2019 и др.).
В других странах (помимо Великобритании и стран Северной Европы, например, в Австралии, Новой Зеландии, США и т.д.) также существуют либо форматы практико-ориентированной аспирантуры, либо аспирантские программы с практической компонентой, однако в данном исследовании мы сосредоточили внимание на тех регионах и учебных заведениях, где происходит активное осмысление и институционализация данных форматов, идут дискуссии вокруг них, происходит интеграция «практики», академии и бизнеса, а также обсуждаются базовые формулировки, основные понятия и принципы и происходит их «кодификация». Перед нами не стоит задача отразить специфику каждого региона в контексте обсуждаемых вопросов, мы стараемся показать и обсудить существующие мнения и дискуссионные платформы.

\section{БИБЛИОГРАФИЯ}

1. Блэк М. Подготовка художников-конструкторов в Королевском колледже искусств // Англия. 1964. № 3.

2. Ковешникова Е.Н., Ковешникова Н.А. Модели дизайн-образования: зарубежный опыт // Известия ТулГУ. Гуманитарные науки. 2014. № 4-2. [Сетевой pecypc]. URL: https://cyberleninka.ru/article/n/modelidizayn-obrazovaniya-zarubezhnyy-opyt (дата обращения: 29.06.2020).

3. Кросс Н. Дизайнерские способы знать («Designerly ways of knowing»). 1982. [Сетевой ресурc]. URL: http:// larossa.co/cross_1982_designerlywaysofknowing.pdf / (дата обращения: 26.06.2020).

4. Круглый стол «Образование в области искусства и дизайна: форматы и перспективы». Школа дизайна НИУ ВШЭ. 20 сентября 2019. [Сетевой ресурс]. URL: https://design.hse.ru/news/1098/ (дата обращения 27.06.2020).

5. Нетесова Н.И. Развитие проектного метода в системе образования // Молодой учёный. 2014. № 19. C. 587-590.

6. Саймон Г. Науки об искусственном. М.: Мир, 1969.

7. Art \& Education / PhD in Practice, Academy of Fine Arts Vienna / [Online]. URL: https://www.artandeducation. net/announcements/109662/phd-in-practiceacademy-of-fine-arts-vienna/ (дата обращения: 26.06.2020).

8. См.: Billett S. Mimetic learning at work: Learning in the circumstances of practice. Cham, Switzerland: Springer, 2014.
9. Candy L., Edmonds E. Practice-based research in the creative arts: Foundations and Futures from the Front Line. LEONARDO, Vol. 51, No. 1. 2018.

10. Candy L. Theory and Practice in Creative Practitioner Research. Unpublished paper based on Keynote Talk to DESIRE2011 conference Eindhoven NL. [Online]. URL: https://www.academia.edu/10331703/Theory_and_ Practice_in_Creative_Practitioner_Research / (дата обращения: 25.05.2020).

11. Candy L. Practice Based Research: A Guide. CCS Report: 2006-V1.0 November/ [Online]. URL: https://www. researchgate.net/publication/257944497 (дата обращения: 27.06.2020).

12. Design Council. [Online]. URL: https://www. designcouncil.org.uk/ (дата обращения: 26.06.2020).

13. Edith Cowan University / Research Methodologies for the Creative Arts \& Humanities: Exegesis. [Online]. URL: https://ecu.au.libguides.com/c. php?g=410634\&p=2797941 / (дата обращения: 25.05.2020).

14. Epstein R. (2005). Generativity theory and creativity. In M.A. Runco \& R. S. Albert (Eds.), Theories of creativity (Rev. ed.). Cresskill, NJ: Hampton Press. 2005. Pp. 116140.

15. Hockey J. Practice - Based Research Degree Students in Art and Design: Identity and Adaptation. International Journal of Art \& Design Education. 22. 2003.

16. Ingold T. Making: Anthropology, archaeology, art and architecture. Oxon: Routledge. 2013. 
17. Interview between the JAWS editorial team and Dr Rachel Hann // Journal of Arts Writing by Students, Volume 5, Number 1, 1 March 2019.

18. Kingston University, London. [Online]. URL: https:// www.kingston.ac.uk/research/research-degrees/ available-degrees/practice-based-phd/ (дата обращения: 25.05.2020)

19. Knoll M. In: Progressive Education Across the Continents. A Handbook, ed. Hermann Röhrs and Volker Lenhart. New York: Lang, 1995.

20. Lawson B. How Designers Think - The Design Process Demystified. University Press, Cambridge. 2005.

21. Lithgow M. and Wall K. Embedded Aesthetics: Artist-inResidencies as Sites of Discursive Struggle and Social Innovation. Seismopolite 19. 2017 / [Online]. URL: http://www.seismopolite.com/embedded-aestheticsartist-in-residencies-as-sites-of-discursive-struggleand-social-innovation (дата обращения: 25.05.2020).

22. Mäkelä M. Knowing Through Making: The Role of the Artefact in Practice-led Research. Knowledge and Policy, 20(3):157-163. October 2007. [Online]. URL: https://www.researchgate.net/publication/227320305_ Knowing_Through_Making_The_Role_of_the_

Artefact_in_Practice-led_Research / (дата обращения 27.06.2020).

23. Pecore J. From Kilpatrick's Project Method to ProjectBased Learning // International Handbook of Progressive Education. 2015.

24. PhDArts / Individual Projects / Resonances between Dance and Gnosis. [Online]. URL: https://www.phdarts.
eu/ResonancesbetweenDanceandGnosis / (дата обращения: 26.06.2020).

25. PhDArts, international doctorate programme in art and design, is a collaboration between Leiden University Academy of Creative and Performing Arts and the Royal Academy of Art (KABK) in The Hague / Requirements. [Online]. URL: https://www.phdarts.eu/Admission/ Requirements / (дата обращения: 26.06.2020).

26. Rust C., Mottram J., Till J. AHRC Research Review: Practice-Led Research in Art, Design and Architecture. 2007 / [Online]. URL: http://www.ahrb.ac.uk/research/ grant/guide.htm [accessed July 2000] / (дата обращения: 26.06.2020).

27. Research Pavilion \#3 Venice 2019. [Online]. URL: http:// www.researchpavilion.fi/ (дата обращения: 26.06.2020).

28. Schön D. A. The reflective practitioner: how professionals think in action, Basic Books: New York. 1983.

29. Skains R. L. Creative Practice as Research: Discourse on Methodology. 2018. 19:1, 82-97. [Online]. URL: https:// www.tandfonline.com/doi/full/10.1080/14682753.2017 .1362175 / (дата обращения: 25.05.2020).

30. Harvey, A. (2017). Art and Design. Critical Survey, 29(1), 133-137. DOI:10.2307/26382293

31. Bigelow, Florence M. «General Principle of Art and Design.» Fine Arts Journal 31, no. 6 (1914): 572-85. Accessed March 22, 2021. DOI:10.2307/25603464

32. Seago, A., \& Dunne, A. (1999). New Methodologies in Art and Design Research: The Object as Discourse. Design Issues, 15(2), 11-17. DOI:10.2307/1511838 